\title{
Pengaruh Gaya Kepemimpinan dan Disiplin Kerja Terhadap Kinerja Pegawai Negeri Sipil di Lanud Haluoleo, Kendari, Sulawesi Tengah
}

\author{
Nana Resmana', Dyah Novita Ratnasari ${ }^{2}$ \\ 1,2 Sekolah Tinggi Penerbangan AVIASI, Jakarta, Indonesia \\ e-mail: nana_resmana@yahoo.co.id,dyahnovitaratnasari@gmail.com
}

\begin{abstract}
This study aims to determine: The effect of leadership style on the performance of civil servants at Lanud Haluoleo, Kendari, Southeast Sulawesi. Effect of work discipline on employee performance. Effect of leadership style and work discipline on the performance of civil servants. This study was categorized as a quantitative associative causal study with an instrument in the form of a questionnaire. The population in this study were 81 civil servants from Lanud Haluoleo. Sampling technique using Sampling Proposal. The sample in this study was to take a population or as many as 81 samples. Data collection using questionnaires and interviews. Test the validity of the instrument using Confirmatory Factor Analysis, while the reliability test uses Cronbach Alpha. The measuring instrument proved to be valid and reliable for research instruments. Multiple regression analysis is used to test the hypothesis of this study.

The results of the study found that: Leadership Style had a positive and significant effect on employee performance by 0.313 with a significance of 0.01 . The contribution of leadership style to employee performance is $9.7 \%$. Work discipline has a significant positive effect on the performance of civil servants Lanud Haluoleo of 0.282 with a significance of 0.05 . The contribution of work discipline to employee performance is $7.5 \%$. Leadership style and work discipline have a positive and significant effect on the performance of civil servants Lanud Haluoleo at ( $\beta$ ) 0.484 with a significance of 0.05 . Contribution of leadership style and work discipline to explain the performance of civil servants at Haluoleo Airport at $14.1 \%$.
\end{abstract}

Keyword : Leadership Style, Work Discipline, Employee Performance.

\section{PENDAHULUAN}

Setiap organisasi atau instansi dalam melaksanakan program selalu diarahkan untuk mencapai tujuan dari organisasi tersebut. Faktor yang menjadi kriteria untuk mencapai kelancaran tujuan suatu organisasi adalah mengidentifikasi dan mengukur kinerja pegawainya. Apabila suatu organisasi mampu 
mencapai tujuan yang telah ditetapkan, maka dapat dikatakan bahwa organisasi tersebut efektif. Seiring dengan berkembangnya waktu, semua organisasi dituntut untuk dapat bersaing memberikan pelayanan yang terbaik, termasuk organisasi pemerintah.

Pelayanan yang terbaik, tidak dapat dilepaskan dari peran setiap pegawainya. Seorang pegawai harus bisa bekerja secara optimal dimana hal ini dapat dilihat atau diukur melalui kinerja pegawai tersebut. Menurut Budi Setiyawan dan Waridin (2006) kinerja pegawai merupakan hasil atau kinerja pegawai yang dinilai dari segi kualitas maupun kuantitas berdasarkan standar kerja yang ditentukan oleh pihak organisasi. Kinerja yang baik adalah kinerja yang optimal, yaitu kinerja yang sesuai standar organisasi dan mendukung tercapainya tujuan organisasi. Organisasi yang baik adalah organisasi yang berusaha meningkatkan kemampuan sumber daya manusianya, karena hal tersebut merupakan faktor kunci untuk meningkatkan kinerja pegawai. Peningkatan kinerja pegawai akan membawa kemajuan bagi instansi (organisasi) untuk dapat bertahan dalam suatu persaingan yang tidak stabil.

Oleh karena itu upaya-upaya untuk meningkatkan kinerja pegawai merupakan tantangan manajemen yang paling serius karena keberhasilan untuk mencapai tujuan dan kelangsungan hidup instansi (organisasi) tergantung pada kualitas kinerja sumber daya manusia yang ada didalamnya.

Menurunnya kinerja pegawai juga disebabkan oleh gaya kepemimpinan yang diterapkan oleh pimpinan. Para pegawai merasa bebas dalam melakukan pekerjaannya sehingga membuat mereka bekerja sesuka hati mereka, karena pimpinan kurang memperhatikan pegawai. Hal ini terlihat dari tidak adanya sanksi langsung yang diberikan kepada pegawai yang kurang disiplin dalam bekerja dan hal ini membuat kecemburuan pada pegawai lainnya, sehingga akan berdampak pada kinerja pegawai secara tidak langsung. Faktor lain yang menyebabkan menurunnya kinerja pegawai adalah lingkungan kerja fisik yang kurang mendukung produktivitas kerja, yaitu ruangan kerja yang gelap, saling terbuka dan berdempetan sehingga pegawai merasa sempit dan masih minimnya kemampuan penggunaan teknologi (komputer). Beberapa pegawai juga menyebutkan menurunnya kinerja disebabkan adanya beban kerja yang tinggi dan minimnya penghargaan yang diberikan atas kinerja yang dicapai oleh para pegawai.

Berdasarkan dari pra-survey yang penulis laksanakan di Lanud Haluoleo, Kendari, Sulawesi Tenggara mengenai faktorfaktor yang mempengaruhi menurunnya kinerja dari para pegawai yang bekerja disana, mendapatkan hasil sebagai berikut : 
Tabel 1. Faktor Yang Harus Mendapat

Perhatian Lebih Dari Instansi Untuk

Meningkatkan Kinerja Pegawai

\begin{tabular}{|l|l|l|l|}
\hline No & $\begin{array}{c}\text { Faktor yang } \\
\text { Mempengaruhi }\end{array}$ & $\begin{array}{c}\text { Jumlah } \\
\text { Jawaban }\end{array}$ & $\%$ \\
\hline 1 & Lingkungan Kerja & 1 & 5 \\
\hline 2 & Disiplin & 9 & 45 \\
\hline 3 & $\begin{array}{l}\text { Penghargaan yang } \\
\text { diberikan }\end{array}$ & 2 & 10 \\
\hline 4 & $\begin{array}{l}\text { Gaya } \\
\text { Kepemimpinan }\end{array}$ & 6 & 30 \\
\hline 5 & Beban Kerja & 2 & 10 \\
\hline
\end{tabular}

Sumber: Observasi dengan 10 orang Pegawai Negeri Sipil di Lanud Haluoleo, Kendari, Sulawesi Tenggara

Setiap pegawai yang menjadi responden diperbolehkan untuk menjawab dua faktor yang mempengaruhi kinerja Pegawai Negeri Sipil di Lanud Haluoleo, Kendari, Sulawesi Tenggara. Responden dalam pra survey memilih dua jawaban karena penelitian ini ingin memfokuskan dua faktor yang paling berpengaruh terhadap kinerja pegawai di Pegawai Negeri Sipil di Lanud Haluoleo, Kendari, Sulawesi Tenggara. Dari hasil pra survey tersebut, terlihat bahwa dua faktor tertinggi adalah Disiplin dan Kepemimpinan, yaitu masing-masing sebesar $45 \%$ atau sebanyak 9 responden dan sebesar 30\% atau sebanyak 6 responden. Faktor paling kecil yang mendukung kinerja pegawai adalah lingkungan kerja yaitu sebesar 5\% atau sebanyak 1 responden.

Dari uraian di atas, maka dapat diidentifikasikan permasalahan yang ada sebagai berikut ; Menurunnya kinerja pegawai berdasarkan dari pencapaian penilaian kinerja instansi, Menurunnya serapan anggaran yang dilakukan oleh Pegawai Negeri Sipil di Lanud Haluoleo, Kendari, Sulawesi Tenggara, Lingkungan kerja yang kurang mendukung produktivitas kerja pegawai, Kurang disiplinnya pegawai dalam bekerja, Masih ada pegawai yang datang terlembat, Masih adanya keterlambatan pengumpulan laporan kegiatan yang dilakukan oleh pegawai, Para pegawai tidak merasa puas akan pekerjaannya dikarenakan tidak adanya penghargaaan yang diberikan atas capaian pekerjaan, dan Beban kerja yang tinggi menurunkan kinerja Pegawai Negeri Sipil di Lanud Haluoleo, Kendari, Sulawesi Tenggara.

Tujuan Penelitian ini untuk mendapatkan informasi mengenai Pengaruh gaya kepemimpinan terhadap kinerja Pegawai Negeri Sipil di Lanud Haluoleo, Kendari, Sulawesi Tenggara, Pengaruh disiplin kerja terhadap kinerja Pegawai Negeri Sipil di Lanud Haluoleo, Kendari, Sulawesi Tenggara, dan Pengaruh gaya kepemimpinan dan disiplin kerja 
terhadap kinerja Pegawai Negeri Sipil di Lanud Haluoleo, Kendari, Sulawesi Tenggara.

Landasan Teori

Hasibuan (2007: 94) kinerja adalah suatu hasil kerja yang dicapai seseorang dalam melaksanakan tugas-tugas yang dibebankan kepadanya didasarkan atas kecakapan, pengalaman, dan kesungguhan serta waktu. Yun (2000:745) menjelaskan bahwa kinerja didefinisikan sebagai perilaku yang terlibat langsung dalam proses produksi barang atau jasa, atau kegiatan yang memberikan dukungan langsung untuk proses teknis dari sebuah organisasi. Suprihatiningrum (2012: 5) menyebutkan bahwa kinerja adalah perbandingan antara penampilan seseorang dengan hasil yang diharapkan. Hermawati (2012: 112) kinerja merupakan hasil kerja seorang pegawai selama periode tertentu dibandingkan dengan berbagai kemungkinan, misalnya standar, target, atau kriteria lain yang telah ditentukan terlebih dahulu oleh perusahaan dan telah disepakati bersama. Dari beberapa pengertian di atas, yang digunakan landasan dalam penelitian ini adalah pengertian yang paling sesuai dengan keadaan dalam organisasi (perusahaan) yaitu pendapat Hermawati (2012) yang menyebutkan bahwa kinerja adalah hasil kerja seorang pegawai selama periode tertentu dibandingkan dengan berbagai kemungkinan, misalnya standar, target, atau kriteria lain yang telah ditentukan terlebih dahulu oleh perusahaan dan telah disepakati bersama. Jadi dapat disimpulkan bahwa kinerja adalah perbandingan hasil kerja seorang pegawai dengan standar tertentu dalam sebuah perusahaan / instansi.

Indikator-indikator Kinerja Menurut Ranupandojo dan Suad (1984: 126) terdapat empat indikator untuk mengukur kinerja pegawai ; Kualitas kerja ; Kualitas kerja yang dimaksud adalah mutu hasil kerja yang didasarkan pada standar yang telah ditetapkan. Kualitas kerja biasanya diukur melalui ketepatan, ketelitian, ketrampilan, dan kebersihan hasil kerja, Kuantitas kerja ; Kuantitas kerja adalah banyaknya hasil kerja sesuai dengan waktu kerja yang ada. Yang perlu diperhatikan dalam kuantitas kerja adalah bukan hasil rutin tetapi seberapa cepat pekerjaan tersebut dapat diselesaikan, Keandalan ; Dapat tidaknya pegawai tersebut diandalkan. Yang dimaksud adalah kemampuan pegawai dalam memenuhi atau mengikuti instruksi, inisiatif, hati-hati, dan kerajinan, Sikap; Sikap pegawai terhadap perusahaan, atasan, maupun teman kerja

Sedangkan menurut Tsui et al (1997) dalam Devi (2009: 31) menyatakan indikator kinerja pegawai berdasarkan perilaku yang spesifik (judgement performance evaluation) antara lain; Kuantitas kerja karyawan, Kualitas kerja karyawan, Efisiensi karyawan, Standar 
kualitas karyawan, Usaha karyawan, Standar profesional karyawan, Kemampuan karyawan terhadap pekerjaan inti, Kemampuan karyawan menggunakan akal sehat, Ketepatan karyawan, Pengetahuan karyawan, Kreativitas karyawan, Indikator yang digunakan dalam penelitian ini merupakan indikator dari Ranupandojo dan Suad (1984), yaitu indikator kualitas, kuantitas, keandalan dan sikap. Indikatorindikator yang dipilih merupakan indikator yang telah disesuaikan dengan kondisi tempat penelitian.

Faktor-faktor yang Mempengaruhi Kinerja; Suprihatiningrum (2012: 22) menyebutkan bahwa terdapat banyak faktor yang dapat mempengaruhi kinerja antara lain ; Motivasi ; Karami et al (2013) mengatakan bahwa motivasi berasal dari bahasa Latin move yang berarti pergerakan atau menggerakkan. Menurut Cong dan Van (2013) motivasi pada dasarnya adalah apa yang mendorong seseorang untuk bekerja dengan cara tertentu dan dengan sejumlah usaha yang diberikan.

Desain pekerjaan merupakan proses penentuan tugas yang akan dilaksanakan, metode yang digunakan untuk melaksanakan tugas, dan bagaimana pekerjaan berhubungan dengan pekerjaan lainnya di dalam organisasi (Simamora 2006). Desain pekerjaan menentukan bagaimana pekerjaan dilakukan, seberapa besar pengambilan keputusan yang dibuat oleh pegawai terhadap pekerjaannya, dan seberapa banyak tugas yang harus diselesaikan oleh pegawai.

Gibson (1996: 75) menyatakan terdapat tiga kelompok variabel yang mempengaruhi kinerja dan perilaku yaitu; Variabel individu yang meliputi kemampuan dan keterampilan, fisik maupun mental, latar belakang, pengalaman, demografi, umur, jenis kelamin, dan sebagainya. Kemampuan dan ketrampilan merupakan faktor utama yang mempengaruhi kinerja individu, Variabel organisasi, yakni sumber daya, kepemimpinan, imbalan, struktur dan desain pekerjaan, Variabel psikologis, yakni persepsi, sikap, kepribadian, belajar, kepuasan kerja dan motivasi. Persepsi, sikap, kepribadian dan belajar merupakan hal yang komplek dan sulit diukur serta kesempatan tentang pengertiannya sukar dicapai, karena seseorang individu masuk dan bergabung kedalam suatu organisasi kerja pada usia, etnis, latar belakang, budaya dan keterampilan yang berbeda satu sama lainnya.

Faktor - faktor yang mempengaruhi kinerja karyawan menurut Sutrisno (2010: 93 94) yaitu ; Efektivitas dan Efisiensi ; Dalam hubungannya dengan kinerja organisasi, maka ukuran baik buruknya kinerja diukur oleh efektivitas dan efisiensi. Masalahnya adalah bagaimana proses terjadinya efisiensi dan efektivitas organisasi. Dikatakan efektif bila 
mencapai tujuan, dikatakan efisien bila hal itu memuaskan sebagai pendorong mencapai tujuan, Otoritas dan Tanggung jawab, Disiplin, Inisiatif

Peniliaian Kinerja, Mangkunegara (2005: 93) mengemukakan bahwa penilaian kinerja pegawai merupakan evaluasi yang sistematis dari pekerjaan pegawai dan potensi yang dapat dikembangkan. Penilaian dalam proses penafsiran atau penentuan nilai, kualitas atau status dari beberapa obyek orang ataupun sesuatu barang. Menurut Handoko (2005: 135), penilaian kinerja adalah proses melalui mana organisasi mengevaluasi atau menilai kinerja pegawai. Kegiatan ini dapat memperbaiki keputusan-keputusan personalia dan memberikan umpan balik kepada para pegawai tentang pelaksanaan kerja mereka, sedangkan penilaian kinerja pegawai negeri sipil berdasarkan Peraturan Pemerintah Republik Indonesia Nomor 46 tahun 2011 tentang Penilaian Kinerja Pegawai Negeri Sipil adalah suatu proses penilaian secara sistematis yang dilakukan oleh pejabat penilai terhadap sasaran kerja pegawai dan perilaku kerja PNS.

Berdasarkan pengertian penilaian kinerja dari beberapa ahli dan juga Peraturan Pemerintah Republik Indonesia dapat disimpulkan bahwa penilaian kinerja merupakan suatu penilaian yang dilakukan kepada para pegawai (pegawai negeri sipil) atas hasil kerja dari masing-masing pegawai (pegawai negeri sipil) yang dilakukan secara sistematis, Berdasarkan Peraturan Pemerintah Republik Indonesia Nomor 46 tahun 2011, Penilaian kinerja PNS dilakukan berdasarkan 5 prinsip, yaitu objektif, terukur, akuntabel, partisipatif, dan transparan. Penilaian kinerja PNS terdiri atas unsur ; Sasaran Kerja Pegawai (SKP) Sasaran Kerja Pegawai yang selanjutnya disingkat SKP adalah rencana kerja pegawai yang disusun berdasarkan rencana kerja tahunan instansi dan target yang akan dicapai dari setiap pelaksanaan tugas jabatan oleh seorang PNS. Rencana dan target kerja tersebut disusun setiap awal tahun oleh pegawai, dan harus disetujui oleh atasan langsung/pejabat penilainya. Sanksi bagi pegawai yang tidak menyusun SKP diatur dalam PP No. 53 Tahun 2011 tentang Hukuman Disiplin Pegawai, Penilaian kinerja dengan menggunakan SKP ini meliputi beberapa aspek, yakni kuantitas, kualitas, waktu dan biaya sesuai dengan karakteristik, sifat dan jenis kegiatan pada masing-masing instansi. Lebih lanjut dijelaskan pula bahwa aspek-aspek tersebut disusun dengan mengacu pada standar teknis kegiatan masing- masing instansi. Adapun penilaian dilakukan dengan membandingkan aspek-aspek penilaian pada target di awal tahun dengan realisasi yang 
dicapai pada akhir tahun, Perilaku Kerja, Selain dengan SKP, kinerja pegawai juga diukur dengan indikator perilaku kerja. Parameter yang digunakan untuk mengukur perilaku kerja adalah orientasi pelayanan, integritas, komitmen, disiplin, kerjasama, dan khusus bagi pejabat struktural ditambah satu dimensi yaitu kepemimpinan. Definisi operasional dari indikator-indikator tersebut adalah sebagaimana dijelaskan dalam penjelasan pasal demi pasal dalam Peraturan Pemerintah No.46 Tahun 2011.

Manfaat Penilaian Kinerja Peningkatan kinerja Dengan adanya penilaian, pegawai memperoleh umpan balik dan dapat memperbaiki kualitas pekerjaan mereka, Kesempatan kerja yang adil Penilaian kerja yang akurat akan menjamin setiap pegawai akan memperoleh kesempatan menempati posisi pekerjaan sesuai kemampuannya, Kebutuhan-kebutuhan pelatihan pengembangan, Melalui penilaian kinerja akan diketahui pegawai mana yang memiliki kemampuan rendah dan kemudian akan ditindak lanjuti dengan adanya program pelatihan untuk meningkatkan kemampuan mereka, Penyesuaian kompensasi, Penilaian kinerja dapat membantu manajer untuk mengambil keputusan dalam menentukan perbaikan pemberian gaji, kompensasi, dan sebagainyadan Keputusan-keputusan promosi dan demosi, dan Penilaian kinerja dapat digunakan untuk mengambil keputusan untuk mempromosikan pegawai yang berprestasi baik dan demosi untuk pegawai yang berprestasi kurang baik. Kesalahan kesalahan desain pekerjaan, Penilaian kinerja dapat digunakan untuk menilai desain kerja, maksudnya yaitu hasil dari penilaian kinerja dapat membantu mendiagnosis kesalahankesalahan dalam desain kerja, Penyimpanganpenyimpangan proses rekruitmen dan seleksi penilaian kinerja dapat digunakan untuk menilai proses rekruitmen dan seleksi pegawai yang sebelumnya. Kinerja yang sangat rendah bagi pegawaibaru mencerminkan adanya penyimpangan-penyimpangan proses rekruitmen dan seleksi (Notoatmodjo, 1998:133-134).

Gaya Kepemimpinan, Pengertian Gaya Kepemimpinan Dalam menyukseskan kepemimpinan dalam organisasi, pemimpin perlu memikirkan dan memperlihatkan gaya kepemimpinan yang akan diterapkan kepada pegawainya. Gaya kepemimpinan atasan dapat mempengaruhi kesuksesan pegawai dalam berprsetasi, dan akan berujung pada keberhasilan organisasi dalam mencapai tujuannya (Suranta, 2002: 38). Pemimpin perlu memikirkan gaya kepemimpinan yang paling tepat, dimana gaya kepemimpinan yang paling tepat yaitu gaya kepemimpinan yang dapat 
memaksimumkan kinerja, dan mudah dalam menyesuaikan dengan segala situasi dalam organisasi.

Gaya kepemimpinan adalah pola tingkah laku yang dirancang sedemikian rupa untuk mengintegrasikan tujuan organisasi dengan tujuan individu untuk mencapai suatu tujuan tertentu (Sholeha dan Suzy, 1996: 54). Sedangkan Mulyadi dan Rivai (2009: 42) menerangkan bahwa gaya kepemimpinan merupakan pola perilaku dan strategi yang disukai dan sering diterapkan oleh seorang pemimpin dalam rangka mencapai sasaran organisasi. Dengan demikian dapat disimpulkan bahwa gaya kepemimpinan yaitu pola perilaku dan strategi yang disukai dan sering diterapkan pemimpin, dengan menyatukan tujuan organisasi dengan tujuan individu atau pegawai, dalam rangka mencapai tujuan atau sasaran yang telah menjadi komitmen bersama. Lebih lanjut Suranta (2002: 35) menjelaskan bahwa gaya kepemimpinan bersifat lentur atau fleksibel, maksudnya adalah gaya kepemimpinan yang biasa diterapkan pemimpin dapat berubah dengan gaya kepemimpianan yang lainnya seiring dengan berubahnya situasi dan kondisi internal organisasi. Sehingga tercapai keefektifan gaya kepemimpinan, dan tercapainya tujuan organisasi, Tipe / Macam Gaya Kepemimpinan, Terdapat lima gaya kepemimpinan menurut Siagian (2002: 75), yaitu ; Tipe pemimpin yang otokratik, Seorang pemimpin yang otokratik adalah Seorang pemimpin yang menganggap organisasi adalah milik pribadi; Mengidentikkan tujuan pribadi dengan tujuan organisasi; Menganggap bahwa sebagai alat mata - mata; Tidak mau menerima kritik, saran dan pendapat; Terlalu tergantung pada kekuasaan formalnya; Dan dalam tindak penggeraknya sering menggunakan approach yang menggunakan unsur paksaan dan puntif (bersifat menghukum), Tipe pemimpin yang militeristik, Seorang pemimpin militeristik berbeda dengan seorang pemimpin modern. Seorang pemimpin yang bertipe militeristik ialah seorang pemimpin yang memiliki sifat sifat sebagai berikut ; Dalam menggerakkan bawahannya sistem perintah yang sering dipergunakan, Dalam menggerakkan bawahannya senang bergantung pada pangkat dan jabatan, Senang kepada formalitas yang berlebih - lebihan.

Disiplin Kerja, Menurut Simamora (1997: 746) disiplin adalah prosedur yang mengoreksi atau menghukum bawahan karena melanggar peraturan atau prosedur. Disiplin kerja adalah suatu alat yang digunakan para manajer untuk berkomunikasi dengan pegawai agar mereka bersedia untuk mengubah suatu perilaku serta sebagai suatu 
upaya untuk meningkatkan kesadaran dan kesediaan seseorang menaati semua peraturan perusahaan dan norma-norma sosial yang berlaku (Rivai, 2004: 33), Hasibuan (2004: 93) berpendapat bahwa kedisiplinan adalah kesadaran dan kesediaan seseorang menaati semua peraturan perusahaan dan normanorma sosial yang berlaku.

Penelitian yang Relevan, Menurut Harlie (2012) dalam jurnal aplikasi manajemen dengan judul penelitian "Pengaruh Disiplin Kerja, Motivasi dan Pengembangan Karier terhadap Kinerja PNS pada PemKab Tabalong di Tanjung Kalimantan Selatan", hasil penelitian menunjukkan disiplin kerja, motivasi kerja dan pengembangan karir berpengaruh positif secara baik secara simultan maupun secara parsial pada kinerja pegawai negeri sipil dan Menurut Patiran (2010) dalam jurnal fokus ekonomi dengan penelitian berjudul "Analisis Faktor Faktor yang Mempengaruhi Kinerja Pegawai Negeri Sipil", hasil analisis menunjukkan bahwa disiplin kerja, pendidikan pegawai dan motivasi kerja memiliki pengaruh positif pada kinerja pegawai negeri sipil baik secara simultan maupun parsial.

Berdasarkan kajian penelitian diatas, maka Gaya Kepemimpinan dan Disiplin Kerja mempengaruhi Kinerja Pegawai :

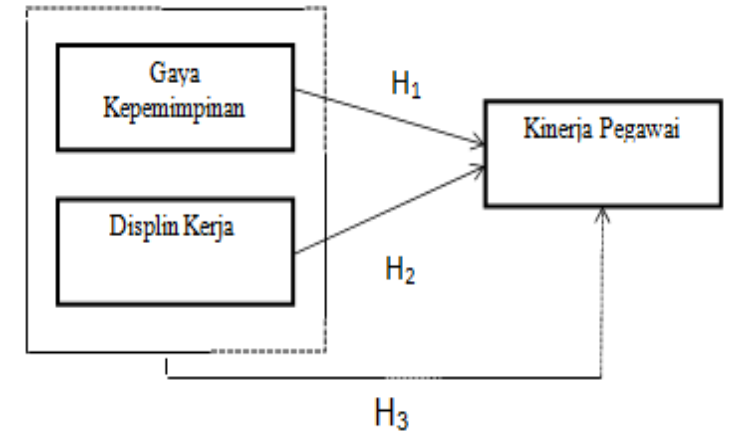

\section{Metode Penelitian}

Penelitian ini termasuk dalam kategori penelitian asosiatif kausal dengan menggunakan pendekatan kuantitatif. Penelitian asosiatif kausal adalah penelitian yang bertujuan untuk mengetahui pengaruh antara dua variabel atau lebih. Penelitian ini akan menjelaskan hubungan mempengaruhi dan dipengaruhi dari variabelvariabel yang akan diteliti, yaitu pengaruh variabel gaya kepemimpinan dan variabel disiplin kerja terhadap variabel kinerja pegawai. Pendekatan kuantitatif digunakan karena data yang akan digunakan untuk menganalisis pengaruh antar variabel dinyatakan dengan angka.

Pengukuran indikator variabel penelitian ini menggunakan Skala Likert, yaitu dengan menyusun pertanyaan atau pernyataan yang masing-masing item diberi range skor dalam Skala Likert.

Metode Analisis data yang digunakan dalam penelitian ini adalah uji masing-masing variabel (menguji variabel $\mathrm{X}$ dan $\mathrm{Y}$ masingmasing sehingga dinyatakan valid dari suatu 
kuesioner yang dibagikan kepada responden), Uji Reabilitas masing-masing variabel (suatu kuesioner dinyatakan reliabel apabila nilai $\mathrm{r}_{\text {hitung }}>$ nilai $\mathrm{r}_{\text {tabel }}$ dengan taraf signifikan 5\%). Analisis Regresi Linier Sederhana merupakan analisis yang ingin mengetahui sampai berapa jauh perubahan satu variabel terhadap variabel lainnya, Uji parsial ( $t$ test)untuk mengetahui pengaruh masingmasing variabel independen terhadap variabel dependen. Uji pengaruh stimultan ( $F$ test) untuk mengetahui apakah variabel independen secara bersama-sama atau stimultan mempengaruhi variabel dependen .Koefisien determinasi untuk mengukur seberapa jauh kemampuan model dalam menerangkan variasi variabel independen.

\section{Hasil dan Pembahasan}

Tabel 1. Descriptive statistics

\begin{tabular}{|c|c|c|c|c|c|}
\hline & $\mathrm{N}$ & $\begin{array}{l}\text { Minimu } \\
\mathrm{m}\end{array}$ & $\begin{array}{l}\text { Maximu } \\
\text { m }\end{array}$ & $\begin{array}{l}\text { Mea } \\
\mathrm{n}\end{array}$ & $\begin{array}{l}\text { Std. } \\
\text { Deviation }\end{array}$ \\
\hline GK & 81 & 1.00 & 4.00 & $\begin{array}{l}2.68 \\
52\end{array}$ & .71783 \\
\hline DK & 81 & 1.38 & 3.25 & $\begin{array}{l}2.47 \\
84\end{array}$ & .44581 \\
\hline KIN & 81 & 2.00 & 4.00 & $\begin{array}{l}3.13 \\
58\end{array}$ & .49659 \\
\hline $\begin{array}{l}\text { Valid } \\
\mathrm{N} \\
\text { (listwi } \\
\text { se) }\end{array}$ & 81 & & & & \\
\hline
\end{tabular}

Tabel 2. Karakteristik Responden berdasarkan Jenis Kelamin

\begin{tabular}{|lll|}
\hline Jenis Kelamin & Frekuensi & Persentase \\
Laki-Laki & 49 & $60,5 \%$ \\
Perempuan & 32 & $39,5 \%$ \\
Total & 81 & $100 \%$ \\
\hline
\end{tabular}

Sumber : Data Primer yang diolah 2018 Tabel 3. Hasil Uji Linieritas

\begin{tabular}{|c|c|c|c|}
\hline \multicolumn{2}{|c|}{ Variabel } & Signifikansi & Keterangan \\
\hline \multicolumn{2}{|c|}{ Gaya Kepemimpinan } & 0,059 & Linier \\
\hline terhadap & Kinerja & & \\
\hline \multicolumn{4}{|l|}{ Pegawai } \\
\hline Disiplin & Kerja & 0,420 & Linier \\
\hline terhadap & Kinerja & & \\
\hline Pegawai & & & \\
\hline
\end{tabular}

Sumber : Data Primer yang diolah 2018

Berdasarkan hasil uji linieritas di atas diketahui bahwa semua variabel independen memiliki hubungan yang linier dengan variabel dependen. Dengan demikian dapat disimpulkan bahwa semua variabel adalah linier.

Tabel 4. Hasil Uji F

ANOVA $^{\mathrm{a}}$

\begin{tabular}{|l|r|r|r|r|}
\hline Model & \multicolumn{1}{|l|}{$\begin{array}{l}\text { Sum of } \\
\text { Squares }\end{array}$} & $\begin{array}{l}\text { Mean } \\
\text { Square }\end{array}$ & F & Sig. \\
\hline Regression & 18.868 & 18.868 & 9.393 & $.003^{\mathrm{b}}$ \\
\hline Residual & 158.687 & 2.009 & & \\
\hline Total & 177.556 & & & \\
\hline Regression & 31.450 & 15.725 & 8.395 & $.000^{\mathrm{c}}$ \\
\hline Residual & 146.106 & 1.873 & & \\
\hline Total & 177.556 & & & \\
\hline
\end{tabular}


a. Dependent Variable: KIN

b. Predictors: (Constant), GK

c. Predictors: (Constant), GK, DK

Tabel 5. Rangkuman Hasil Analisis Regresi, gaya kepemimpinan dan disiplin kerja terhadap kinerja pegawai.

\begin{tabular}{|c|c|c|c|c|}
\hline \multirow{2}{*}{ Variabel. } & Model1 & Model2 & Model3 & Model4 \\
\hline & Beta & Beta & Beta & Beta \\
\hline Jenis Kelamin & .125 & .112 & .089 & .086 \\
\hline Pendidikan & $.295^{8}$ & $.289^{\circ}$ & .225 & $.235^{8}$ \\
\hline Jabatan & .024 & .047 & .002 & .023 \\
\hline GK & & $.313^{* *}$ & & $.264^{*}$ \\
\hline DK & & & $.282^{*}$ & $.220^{*}$ \\
\hline$R^{2}$ & .087 & .184 & .162 & .228 \\
\hline$\Delta R^{2}$ & .087 & $.097^{* *}$ & $.075^{*}$ & $.141^{*}$ \\
\hline
\end{tabular}

Dari hasil penelitian diketahui adanya pengaruh positif gaya kepemimpinan terhadap kinerja pegawai. Hal ini dibuktikan dengan $\beta=0,313(* * p<0.01 ; p=0,004)$. Kontribusi gaya kepemimpinan untuk menjelaskan kinerja pegawai sebesar $\left(\Delta R^{2}\right)$ 0,097. Skor tertinggi indikator variabel gaya kepemimpinan terdapat pada indikator cara pandang $(2,72)$.

Pimpinan Di Lanud Haluoleo, Kendari, Sulawesi Tenggara berusaha meningkatkan kinerja pegawainya dengan cara mempengaruhi cara pandang pegawai dalam menyelesaikan pekerjaannya, sehingga antara pimpinan dan pegawai memiliki visi dan misi yang sama, dengan kesamaan ini dapat membuat mereka bekerja untuk mencapai satu target yang sama (yang telah disepakati bersama), sehingga dalam bekerjapun mereka akan lebih fokus untuk mencapai satu hal secara bersama-sama dan dalam bekerja mereka tidak akan ada yang mengerjakan pekerjaan yang tidak mendukung dari target bersama tersebut (mencapai target yang lain). Hal ini tentunya dapat meningkatkan kinerja pegawai ke tingkat yang lebih tinggi karena seluruh sumber daya manusia yang ada bekerja dengan satu tujuan yang sama. Alasan ini diperkuat dengan teori dari Robbins (2008) yang dalam penjelasannya disebutkan bahwa pemimpin mampu merangsang agar bawahan dapat berfikir secara kreatif dan inovatif dalam melaksanakan dan mencapai pekerjaan (target). Selanjutnya dalam penelitian Suranta (2002: 84) mengatakan bahwa gaya kepemimpinan berpengaruh dalam meningkatkan kinerja pegawai dengan mempengaruhi perilaku dan cara pandang karyawan.

Pengaruh Disiplin Kerja terhadap Kinerja Pegawai Hasil penelitian ini juga menunjukkan bahwa terdapat pengaruh positif antara disiplin kerja terhadap kinerja pegawai di Di Lanud Haluoleo, Kendari, Sulawesi Tenggara. Hal ini dibuktikan dengan $\beta=0,282$ 
$\left({ }^{*} \mathrm{p}<0.05 ; \mathrm{p}=0,011\right)$. Kontribusi disiplin kerja untuk menjelaskan kinerja pegawai sebesar $\left(\Delta R^{2}\right) 0,075$.

Pengaruh disiplin kerja terhadap kinerja pegawai dapat dijelaskan dengan beberapa faktor. Indikator kehadiran memiliki skor tertinggi yaitu 1,83. Berdasarkan lokasi penelitian, masih terlihat adanya ketidak disiplinan kerja dalam indikator kehadiran ini, karena masih ada pegawai yang terlambat untuk datang ke kantor dan juga ada pegawai yang terkadang meninggalkan kantor saat jam kerja masih berlangsung untuk kegiatan yang tidak ada hubungannya dengan pekerjaan kantor. Hal ini tentunya akan berpengaruh terhadap kinerja mereka, karena dengan mereka datang terlambat ataupun meninggalkan kantor dan pekerjaan pada saat jam kerja untuk melaksanakan pekerjaan yang tidak ada hubungannya dengan pekerjaan kantor tentunya ini akan mengurangi jumlah dan capaian pekerjaan yang dapat mereka kerjakan pada hari itu, sehingga hal tersebut akan menunda selesainya pekerjaan yang mereka kerjakan. Hal ini menunjukkan bahwa penting bagi para pegawai untuk selalu hadir dan tidak meninggalkan pekerjaannya, karena dengan minimnya tingkat ketidakhadiran pegawai dapat membuat pegawai tersebut bertanggungjawab atas setiap tugas yang diberikan dari pimpinan. Pernyataan ini sesuai dengan pendapat yang disampaikan oleh Sastrohadiwiryo (2003: 291) menyatakan disiplin kerja sebagai suatu sikap menghormati, menghargai, patuh, dan taat terhadap peraturan-peraturan yang berlaku baik yang tertulis maupun yang tidak tertulis serta sanggup menjalankannya dan tidak mengelak untuk menerima sanksi apabila melanggar tugas dan wewenang yang diberikan kepadanya.

Pendapat dari Sastrohadiwiryo tersebut terlihat bahwa peraturan sangatlah penting, dimana absensi pegawai adalah salah satu peraturan yang penting sehingga setiap pegawai harus patuh dalam melaksanakannya. Kedisiplinan dalam bekerja yang dilihat dari absensinya secara otomatis dapat menciptakan pegawai yang mampu mengerjakan tugasnya secara optimal. Tugas yang mampu dikerjakan secara optimal akan mempengaruhi tingkat kinerja pegawai itu sendiri.

Pengaruh Gaya Kepemimpinan dan Disiplin Kerja terhadap Kinerja Pegawai, Gaya kepemimpinan dan disiplin kerja dalam penelitian ini secara bersamaan berpengaruh positif terhadap kinerja pegawai. Hidayat, dkk (2006) berpendapat bahwa gaya kepemimpinan berpengaruh positif terhadap kinerja pegawai, Harlie (2012) berpendapat bahwa disiplin kerja berpangaruh positif terhadap kinerja pegawai. Berdasarkan hasil penelitian ini, skor tertinggi 
variabel gaya kepemimpinan terdapat pada indikator cara pandang. Sedangkan skor tertinggi variabel disiplin kerja terdapat pada indikator kehadiran. Pimpinan Di Lanud Haluoleo, Kendari, Sulawesi Tenggara telah memberikan peraturan yang harus dipatuhi, salah satunya adalah kehadiran pegawai itu sendiri. Ketika tingkat kehadiran pegawai itu tinggi maka waktu mereka berada di tempat kerja untuk mengerjakan pekerjaan juga lebih banyak.

Selain itu, dengan pengaruh pimpinan yang dapat mempengaruhi cara pandang atau pola pikir pegawai dalam menyelesaikan pekerjaannya mampu membuat para pegawai lebih kreatif dan inovatif dalam melaksanakan setiap pekerjaan yang diberikan kepadanya. Penjelasan ini membuktikan bahwa dengan adanya tingkat kehadiran yang tinggi dan pengaruh pimpinan dalam mempengaruhi cara pandang pegawai dapat membuat kinerja pegawai menjadi semakin optimal. Hal ini sejalan dengan penelitian Reza (2010) yang mengatakan bahwa kinerja yang tinggi dapat dicapai oleh seorang karyawan berkat adanya kepatuhan terhadap aturan serta dukungan dari atasannya. Berdasarkan penjelasan di atas dan hasil penelitian Reza (2010) semakin menguatkan pendapat bahwa disiplin kerja dan gaya kepemimpinan secara ersama berpengaruh terhadap kinerja karyawan.

\section{KESIMPULAN}

Gaya kepemimpinan $\left(\mathrm{X}_{1}\right)$ memiliki pengaruh positif dan signifikan (tingkat signifikansi 99\%) terhadap kinerja pegawai (Y) Di Lanud Haluoleo, Kendari, Sulawesi Tenggara. Hal ini dapat dibuktikan melalui analisis regresi yang diperoleh nilai hasil pengujian menunjukkan nilai $\beta$ sebesar 0,313 dan $\Delta \mathrm{R}^{2}$ sebesar 0,097 yang artinya gaya kepemimpinan memiliki pengaruh positif terhadap kinerja pegawai sebesar 9,7\%. Berdasarkan hal tersebut dapat disimpulkan gaya kepemimpinan memiliki pengaruh positif dan signifikan terhadap kinerja pegawai Di Landasan udara Haluoleo, Kendari, Sulawesi Tenggara dan dapat disimpulkan pula hipotesis pertama diterima. Jadi, jika gaya kepemimpinan yang diterapkan oleh pimpinan dilakukan dengan baik maka kinerja pegawai juga akan mengalami peningkatan.

Disiplin kerja $\left(\mathrm{X}_{2}\right)$ memiliki pengaruh positif dan signifikan (tingkat signifikansi 95\%) terhadap kinerja pegawai (Y) Di Landasan udara Haluoleo, Kendari, Sulawesi Tenggara. Hal ini dapat dibuktikan melalui analisis regresi yang diperoleh nilai hasil pengujian menunjukkan nilai $\beta$ sebesar 0,282 dan $\Delta \mathrm{R}^{2}$ sebesar 0,075 yang artinya disiplin kerja memiliki pengaruh positif terhadap kinerja pegawai sebesar 7,5\%. Berdasarkan hal 
tersebut dapat disimpulkan disiplin kerja memiliki pengaruh positif dan signifikan terhadap kinerja pegawai Di Lanud Haluoleo, Kendari, Sulawesi Tenggara dan dapat disimpulkan pula hipotesis kedua diterima. Jadi, jika karyawan disiplin dalam bekerja maka kinerja pegawai juga akan tercapai dan mengalami peningkatan.

Gaya Kepemimpinan dan disiplin kerja memiliki pengaruh positif dan signifikan (tingkat signifikansi 95\%) terhadap kinerja pegawai Di Lanud Haluoleo, Kendari, Sulawesi Tenggara. Hal ini dibuktikan melalui analisis regresi nilai $\beta$ gaya kepemimpinan sebesar 0,264 , nilai $\beta$ disiplin kerja sebesar 0,220 dan $\Delta R^{2}$ sebesar 0,141 yang artinya gaya kepemimpinan dan disiplin kerja memiliki pengaruh positif terhadap kinerja pegawai sebesar $14,1 \%$ dan dapat disimpulkan pula bahwa hipotesis ketiga diterima. Jadi, semakin tepat gaya kepemimpinan yang diterapkan oleh pimpinan dan tingkat kedisiplinan kerja pegawai semakin baik maka kinerja dari pegawaipun juga akan lebih baik lagi (meningkat).

\section{DAFTAR PUSTAKA}

Arikunto, Suharsimi. (2010). Manajemen Penelitian. Jakarta: Rineka Cipta. Aritonang, Keke T. (2005). Kompensasi Kerja, Disiplin Kerja Guru dan Kinerja Guru SMP Kristen BPK

Penabur Jakarta. Jurnal Pendidikan

Penabur, 4 (Th.IV), Juli 2005.

Devi, Eva Kris Diana. (2009). Analisis Pengaruh Kepuasan Kerja dan Motivasi terhadap Kinerja Karyawan dengan Komitmen Organisasional Sebgai variabel Intervening. Tesis: Program Studi Magister Manajemen Program Pasca Sarjana Universitas Diponegoro.

Dharmawan, I Made Yusa. (2011). Pengaruh Kompensasi dan Lingkungan Kerja Non Fisik terhadap Disiplin Kerja dan Kinerja Karyawan Hotel Nikki Denpasar. Tesis: Program Studi Magister Manajemen Program Pasca Sarjana Universitas Udayana.

Ghozali, Imam. (2011). Aplikasi Analisis Multivariate Dengan Program IBM SPSS 19.Semarang: Badan Penerbit Universitas Diponegoro.

Gibson, James, et al. (1996). Organisasi Perilaku, Struktur, dan Proses. (Alih Bahasa: Nunuk Adiarni). Jakarta: Binarupa Aksara. 
Gujarati, D. N. (2012). Basic Econometrics. New-York: McGraw-Hill Education.

Handoko, T. Hani. (2003). Manajemen Edisi 2. Yogyakarta: BPFE.

Harlie, M. (2012). Pengaruh Disiplin Kerja, Motivasi dan Pengembangan Karier terhadap Kinerja PNS pada PemKab Tabalong di Tanjung Kalimantan Selatan. Jurnal Aplikasi Manajemen Vol. 10, No. 4, Desember 2012 : $860-$ 867.

Hasibuan, Malayu. (2004). Manajemen Sumber Daya Manusia. Jakarta: PT. Bumi Aksara.

Hermawati, A. (2012). Pengaruh Motivasi dan Kemampuan terhadap Prestasi Kerja Pegawai Dinas Pendidikan Pemerintah Kota Batu. Jurnal Dinamika Dotcom,3(2), 107-120.

Hidayat,. dkk. (2005). Pengaruh Motivasi Kerja, Kemampuan Kerja, dan Gaya Kepemimpinan terhadap Kinerja Karyawan pada Badan Kesatuan Bangsa dan Perlindungan Masyarakat Propinsi Jawa Tengah. Jurnal Ilmu
Administrasi dan Kebijakan Publik, Vol. 3, No. 1, Januari 2006 : 89-97.

Mariam, Rani. (2009). Pengaruh Gaya Kepemimpinan dan Budaya Organisasi terhadap Kinerja Karyawan Melalui Kepuasan Kerja Karyawan sebagai Variabel Intervening. Tesis: Program Studi Magister Manajemen Program Pasca Sarjana Universitas Diponegoro.

Marifah. (2004). Pengaruh Motivasi Kerja dan Budaya Organisasi Terhadap Kinerja Pekerja Sosial di Lingkungan UPTD Sosial Provinsi Jawa Timur. Tesis: Program Studi Magister Manajemen Program Pasca Sarjana Universitas Airlangga.

Mas'ud, Fuad. (2004). Survey Diagnosis Organizational. Semarang : UNDIP. Mawar. (2007). Pengaruh Kompensasi, Pelatihan, Kepemimpinan, dan Lingkungan Kerja terhadap Kinerja Pegawai di PT.Askes (Persero) Kantor Cabang Denpasar. Tesis: Magister Manajemen Unversitas Udayana. 
Notoatmodjo, S. (1998). Pengembangan Sumber Daya Manusia (Edisi Revisi). Jakarta: PT Rineka Cipta.

Nugroho, Rahmat. (2006). Analisis FaktorFaktor Yang Mempengaruhi Kinerja Karyawan, Studi Empiris pada PT. BTN (persero) Cab. Bandung. Tesis: Program Studi Magister Manajemen Program Pasca Sarjana Universitas Diponegoro.

Patiran, Andarias. (2010). Analisis Faktor Faktor yang Mempengaruhi Kinerja Pegawai Negeri Sipil (PNS). Jurnal Fokus Ekonomi, Vol. 5, No. 2, Desember $2010: 32-43$.

Peraturan Kepala Badan Kepegawaian Negara Nomor 1 Tahun 2013 tentang Ketentuan Pelaksanaan Peraturan Pemerintah Nomor 46 Tahun 2011 Tentang Penilaian Prestasi Kerja Pegawai Negeri Sipil.

Peraturan Pemerintah Republik Indonesia Nomor 46 Tahun 2011 tentang Penilaian Prestasi Kerja Pegawai Negeri Sipil.
Ranupandojo, Heidjrahman dan Suad Husnan. (1984). Manajemen Personalia, Edisi Ketiga. Yogyakarta: BPFE UGM.

Reza, Regina Aditya. (2010). Pengaruh Gaya Kepemimpinan, Motivasi, dan. Disiplin Kerja terhadap Kinerja Karyawan PT. Sinar Santosa Perkasa Banjarnegara. Skripsi: Program Sarjana Fakultas Ekonomi Diponegoro.

Rivai, Veithzal. ( 2004). Manajemen Sumber Daya Manusia Untuk Perusahaan. Jakarta: PT. Raja Grafindo Persada.

Rivai, Veithzal \& Dedy Mulyadi. (2009). Kepemimpinan Dan Perilaku Organisasi. Jakarta: PT. Raja Grafindo Persada.

Robbins, Stephen P. \& Timothy A. Judge. (2008). Perilaku Organisasi. Edisi Kedua Belas. Jakarta: Salemba Empat.

Sastrohadiwiryo, B. Siswanto. (2003). Manajemen Tenaga Kerja Indonesia. Jakarta: Bumi Aksara.

Setyawan, Budi \& Waridin. (2006). Pengaruh Disiplin Kerja Karyawan dan Budaya Organisasi terhadap Kinerja di Divisi 
Radiologi RSUP dr. Kariadi Semarang. JRBI. Vol 2. No 2. Hal: 181-198.
Journal of Applied Psychology, 92(3), 745-756.

Siagian, Sondong P. (2002). Kiat Meningkatkan

Produktivitas Kerja. Jakarta: PT. Rineka Cipta.

Simamora, Henry. (1997). Manajemen Sumber Daya Manusia Yogyakarta: YKPN.

Sugiyono. (2008). Metode Penelitian Kunatitatif Kualitatif dan $R \& D$. Bandung: Alfabeta.

Suranata, Sri. (2002). Dampak Motivasi Karyawan Pada Hubungan Antara Gaya Kepemimpinan Dengan Kinerja Karyawan Perusahaan Bisnis. Jurnal Empirika, Vol. 15 (2), Desember : 116 $-138$.

Triantoro, Safaria. 2004. Kepemimpinan. Cetakan Pertama. Surabaya: CV. Graha Sejati Klaten.

Yun, S.,Riki, T., \& Wei, L. (2007). Employee Self-Enhancement Motives and Job Performance Behaviors: Investigating the Moderating Effects of Employee Role Ambiguity and Managerial Perceptions of Employee Commitment. 